\title{
Finger Print of Arsenic Contaminated Water in India-A Review
}

\author{
Neha Chaurasia ${ }^{1 *}$, Amarnath Mishra² and S K Pandey ${ }^{1}$
}

${ }^{1}$ Department of Forensic Medicine, Institute of Medical Sciences, Banaras Hindu University, Varanasi, India

${ }^{2}$ Department of Forensic science Shaits, Allahabad, India

\begin{abstract}
The present study deals primarily with the arsenic contamination occur in ground water in all over India, its causes, effects and recommendation. Arsenic above permissible limit in ground water of phreatic younger alluvium of Ganga and Ghaghara rivers along meandering course and shallow aquifer, has reported as the main source of arsenic contamination. Several studies have been carried out on this context; which is still limited by a lack of data thus, a review study has been undertaken on the sources, causes and health prospective, arsenic is likely to disastrous effects on human. Due to excess of Arsenic in ground water people are reported to be suffering from diseases like skin cancer, ulcer and pigmentation in skin and hardening in palm skin. Different analytical methods have been proposed for further analysis to provide details to know the quantity of arsenic in water, its impact, identify the risk factors and possible to makes recommendation for the prevention and management of arsenic poisoning cases and study of probability of other heavy metals. This review work suggests that the arsenic concentration increase day by day through different channel. It's directly and indirectly affecting human being; needs to be investigating thoroughly arsenic problem in India.
\end{abstract}

Keywords: Arsenic poisoning; Causes; Effects; Heath prospective; Permissible limit; Sources

\section{History and Background}

Safe water is a fundamental human right and it's a basic need of individual. In ancient Greek and Romans period arsenic was known as therapeutic agent [1]. Now day's therapeutics arsenicals are of importance only in the treatment of certain tropical diseases [2]. Over the past three decades, occurrence of high concentrations of arsenic in drinking water has been recognized as a major public-health concern in several parts of the world.

The impact of arsenic on health is more from natural, industrial and environmental than from medicinal exposure [2]. Drinking water is one of the most important pathways of exposure to arsenic, in human and ground water. As a drinking source and it's responsible for chronic arsenic related health problems. The biological, toxicological and environmental significance of arsenic have been written by several authors who have been quoted by Harvey [2].

In India Arsenic contamination $1^{\text {st }}$ foot print are reported in Punjab, Haryana, Himachal Pradesh and Uttar Pradesh [3] . In 1984 ground water arsenic contamination was identify in lower Ganga plain of West Bengal [4]. In 1992 arsenic groundwater contamination in Bangladesh reported [5]. In 2001 groundwater arsenic contamination in the lower Plain area (Terai) of Nepal came to notice [6]. In 2002 June arsenic contamination located in Bihar in middle Ganga plain and at the same time apprehended contamination in Uttar Pradesh lying in middle and upper Ganga plain [7]. During October 2003-August 2005 three districts of UP namely, Ballia, Gazipur and Varanasi is present in the hit list [8].

In January 2004, 17 villages of the Sahibgunj district of Jharkhand state, in the middle Ganga plain are reported affected [9]. Simultaneously January-February 2004 in Assam two districts had an arsenic concentration above $50 \mu \mathrm{g} / \mathrm{L}$ [10]. All the states and countries surveyed in the Ganga-Meghan-Brahmaputra (GMB) plain, which has an area of approximately $500,000 \mathrm{~km}^{2}$ and a population over 500 million, are at risk from groundwater arsenic contamination [10].

\section{Source of Arsenic Contamination in Ground Water}

Arsenic contamination of ground water may occur in two ways: anthropogenic activities and aquifer naturally contain. Ground water contamination cross the permissible limit of WHO $(.01 \mathrm{mg} / \mathrm{l})$, excess arsenic has been detected in tube well/ hand pump drinking water supply in many country about 200 million people under risk. Arsenic found in widely the earth's crust, it's mostly in organic, inorganic and gas form. Organic arsenic abundantly found in sea food, it's not harmful and Inorganic arsenic that is found in ground water is harmful to health because it's stored in the body, thus adversely affecting multiple organ systems and form many diseases.

The toxicity of arsenic follows the order- Arsine gas $>$ Inorganic As (iii) $>$ Organic As (iii) $>$ Inorganic As (v) $>$ Organic As (v) $>$ Elemental As.

Arsenic is 60 times more toxic than arsenate [11], Long term exposure to arsenic in drinking water is casually related to increased risks of cancer in the skin, lung, bladder and kidney, as well as other skin change such as hyperkeratosis and pigmentation change increased risks of lung and bladder cancer of arsenic associated skin lesion have been reported to be associated with ingestion of drinking water at concentration $>50 \mu \mathrm{g} / \mathrm{l}[12]$.

\section{Theories behind Arsenic Occurrence}

\section{Reduction dissolution theory:}

Reductive dissolution of iron oxihydraoxide $(\mathrm{FeOOH})$ and release

*Corresponding author: Neha Chaurasia, Department of Forensic Medicine Institute of Medical Sciences, Banaras Hindu University, Varanasi, India, E-mail: nehaforensicgkp@gmail.com

Received October 17, 2012; Accepted November 26, 2012; Published November 28,2012

Citation: Chaurasia N, Mishra A, Pandey SK (2012) Finger Print of Arsenic Contaminated Water in India-A Review. J Forensic Res 3:172 doi:10.4172/2157 7145.1000172

Copyright: (c) 2012 Chaurasia N, et al. This is an open-access article distributed under the terms of the Creative Commons Attribution License, which permits unrestricted use, distribution, and reproduction in any medium, provided the original author and source are credited. 
of sorbed arsenic to ground water $[13,14]$. Arsenic was naturally transported by river system of Himalaya and adsorbed on to finegrained iron and manganese hydroxide. These are deposited in the flood plain and buried in the sedimentary pile of sediments.

\section{Microbial oxidation theory}

Microbial oxidation of organic carbon due to occurrence of peat deposits depleted the dissolved oxygen in the ground water thus creating a strongly reducing environment [15].

\section{Oxidation of Arsenical Pyrite theory}

Oxidation of Arsenical Pyrite in this theory, arsenic is released by oxidation of arsenical pyrite in alluvial sediments since pumping drawdown permits atmospheric oxygen to invade the aquifer. As the water level rise due to recharge during monsoon arsenic leaches out of sediments into aquifer [16].

\section{Anion exchange theory}

1. Anion exchange of sorbed arsenic with phosphate from fertilizer, arsenic anions sorbed to the aquifer minerals are displaced into solution by competitive exchange of phosphate anion derived from over application of fertilizer.

2. Withdrawal of ground water for irrigation may have mobilized the phosphate in fertilizer and also from decay of natural organic matter in shallow aquifers [16].

One theory proposed to explain the occurrence of arsenic in ground water is that over abstraction of ground water leads to lowering of the water table thus exposing previously submerged sediment of the atmosphere, under natural condition the greatest range and highest concentration of arsenic are found in ground water as a result of the strong influence of the water- rock interaction and the favorable physical and geochemical condition in aquifer for the mobilization and accumulation of arsenic. Arsenic is particularly mobile at $\mathrm{pH}$ value typically found in ground water (6.5-8.5) under both oxidation and reduction condition [15].

In some state of India arsenic in ground water due to geological in origin. It's believed that rocks containing arsenic were eroded from the Himalaya and deposited in the gangatic plains and delta as sediment. This sediment buried over thousands of year of deposition and formed the aquifer that is tapped for water resources.

\section{Permissible limit}

Earlier maximum permissible limit of arsenic for drinking water was $50 \mathrm{ppb}$. Recently World Health Organization has reduced its permissible limit to $10 \mathrm{ppb}$ for drinking water purpose. In India, Department of Drinking Water Supply Ministry of Rural Development has yet its 50ppb to be used for time being.

\section{Global Scenario}

Arsenic level beyond permissible limits in drinking water is the main cause of arsenic toxicity in the world. Taiwan, China, Chile, Argentina, Mexico, India, Hungary Bangladesh, USA and Thailand Reported such type of contamination.

More than 20 Country, including India, is in the midst of a large scale thread cause by chronic mass toxicity through arsenic contamination of ground water. However the largest number of people in the world affected by chronic Arsenic toxicity due to drinking of arsenic contamination ground water belongs to Bangladesh, India and China [12].

\section{Indian Scenario}

Investigations by Central Ground Water Board (CGWB) reveals that arsenic contamination $(>0.05 \mathrm{mg} / \mathrm{L})$ is affecting the states of West Bengal, Bihar, Uttar Pradesh, Assam, Chhattisgarh. The Bengal Delta Plain (BDP) covering Bangladesh and West Bengal in India is the most severe case of groundwater arsenic contamination. Besides this high Arsenic ground water has also been reported from Jharkhand and Manipur state.

\section{West Bengal}

79 blocks in 8 districts have beyond permissible limit of $.05 \mathrm{mg} / \mathrm{l}$ [17].

\section{Most affected areas}

Eastern side of Bhagirathi River in the districts of Malda, Murshidabad, Nadia, North 24 Parganas and South 24 Parganas. And western side of the districts of Howrah, Hugli and Bardhman are mostly affected with arsenic contamination.

\section{People at risk}

162.6 lakh people (35.48\% of the total population of the state) live in the risk zone.

\section{Bihar}

Initially detected in the year 2002 from Semariya-Ojhapatti villages of Bhojpur district. 57 blocks, in 15 districts are under high arsenic contamination risk [18].

\section{Most affected areas}

Arsenic groundwater contamination in Bihar was initially detected in the year 2002 from Semariya-Ojhapatti villages of Bhojpur district. Detailed investigations in the Gangetic Plain of Bihar revealed its wide occurrence on both the banks of the river Ganga.

\section{Chhattisgarh}

Arsenic contamination in ground water is reported along the N-S trending $80 \mathrm{~km}$ stretch of Kotri lineament from Chhattisgarh State. The severity is found in eastern part of Ambagarh Chowki block of Rajnandgaon district.

\section{Most affected Areas}

Arsenic affected villages are Kaurikasa, Joratari, Sonsaytola, Jadutola, Muletitola.

\section{Jharkhand}

Arsenic in water (>.05mg) are reported from 3 blocks of Sahebganj district of Jharkhand (SOES) [19]. CGWB has reported in its studies during 2006-07 that one block i.e Sahebganj block of Sahebganj district was affected with High Arsenic. Later on studies by PHED and CGWB confirmed that three blocks of the districts

\section{Most affected areas}

Rajmahal, Udohwa and Sahebganj districts located on the alluvial deposits has reported affected.

\section{Assam and Manipur}

Studies (by SOES) reveal that 27 villages of Dhemaji and Karimganj district of Assam and Parts of Thumbil \& Imphal district of Manipur are affected by Arsenic contamination $>0.05 \mathrm{mg} / \mathrm{l}$. 
Citation: Chaurasia N, Mishra A, Pandey SK (2012) Finger Print of Arsenic Contaminated Water in India-A Review. J Forensic Res 3:172. doi:10.4172/2157-7145.1000172

Page 3 of 4

\section{Uttar Pradesh}

A combined studied done by U.P. Jal Nigam and UNICEF, it was realized that Arsenic is geogenic in nature in U.P. and is found in younger alluvium. On the basis of this 289 blocks of 49 additional districts were identified at risk. In the identified blocks of 49 districts screening/ blanket tests were performed as per above methodology i.e. screening and blanket testing. The test results showed that Arsenic above $50 \mathrm{ppb}$ (limit set as safe by Department of Drinking Water, GoI) was found in 18 districts and Arsenic in the range of 10 (limit set by WHO) $50 \mathrm{ppb}$ was discovered in 31 districts [20].

Arsenic contamination in India is mainly geogenic and mostly occurs in unconsolidated sediments except in Chhattisgarh where it occurs in aquifers in Precambrian rocks.

\section{Effect of Arsenic Contaminated Drinking Water in Human Biological System}

Serious health hazards can be occurred due to arsenic contaminated drinking water use after a long period of about 5 to 15 years, but the duration can even be 2.5 years for high exposure of contamination [21]. The first cases of arsenicosis in West Bengal were identified in 16 patients from one village of a district in July 1983. Most reports of chronic arsenic exposure focus on dermatological manifestations, In India, they are most common in the basins of Ganga and Brahmaputra [22].

Datta and Kaul [23] further reported high content of arsenic in the liver of five of nine patients with non-cirrhotic portal hypertension $(\mathrm{NCPH})$ who had been drinking arsenic-contaminated water. To date, no further information on arsenic poisoning from northern India is available [3].

Arsenic contamination in many blocks, villages from Ballia district, and another two new districts Gazipur and Varanasi is coming to the forefront and done medical surveys in Ballia showed that 153 (15.47\%) of 989 people screened so far for arsenical skin lesions were registered with skin lesions [23]. In Jharkhand of four villages surveyed for arsenical patients, could find patients in three. In Ballia, 320 villagers screened so far by medical team, 87 were registered with arsenical skin lesions [24]. In Rajnandangaon district of Chhattisgarh have Neurological studies performed on 61 persons showed positive signs of poisoning in $34 \%$ of the population examined. Another study revealed that the number of people at risk is 10,000 [25].

Methods use for mitigation of arsenic in water

\section{For mitigation of arsenic in water to step up some necessary steps:}

- Surface water based piped water supply system wherever feasible, is the most appropriate and sustainable solution for arsenic problems in groundwater based drinking water sources.

- There should also be a separate Department constituted in the District hospital for treating arsenicosis.

- Medical person appoint by state govt. with arsenic mobile team, which is find out number of patient in particular area like in a block -wise, in a village- wise.

- Provide Spot test facility and registered affected location.

- One call center in each District to Registered affected Person.

- Mass awareness programs
Technologies available for removal of arsenic from drinking water

The following are the different techniques available for removal of Arsenic from drinking water.

1. Adsorption on different media

2. Bioremediation and In- situ remediation

3. Coagulation-flocculation-Sedimentation-filtration (Co-precipitation)

4. Ion exchange

5. Iron coated sand

6. Low pressure Nanofiltration

7. Oxidation of Arsenic (III)

8. Passive sedimentation

9. Reverse Osmosis and electro dialysis

10. Solar oxidation

\section{Conclusion}

In this review study has been completed in concise form to compile important information in order to propose remedial measures of arsenic in the context of India. This review work suggests that Arsenic contamination of groundwater and related health hazards are becoming High-profile problems throughout the world. Number of Aquifers has been identified with problems of high Arsenic concentration in ground water. Safe water is not a demand of single person; it's the problem of majority of population. Most of the people suffering from arsenicosis, they are belong to very poor family and their socio-economic status is very low, so they not able to use costly technique for mitigation of arsenic in water. Over all study concludes that Uttar Pradesh is the Capitan of arsenic contamination of ground water. Arsenic infested area Various Arsenic mitigation options include using surface sources, exploring and harnessing alternate arsenic free aquifer, removal of Arsenic from ground water using treatment filters and rainwater harvesting are used but proper implementation is necessary task. We must understand that so far there is no available medicine for chronic arsenic toxicity; safe water, nutritious food, vitamins and physical exercise are the only preventive measures to fight the chronic arsenic toxicity.

\section{References}

1. WHO (1972) Health Hazards of the human Environment. Geneva, 174-178.

2. Goodman LS, Gilman A (1975) The Pharmacological Basis of Therapeutics, (5thedn) McMillan Press, New York, USA.

3. Datta DV, Kaul MK (1976b) Arsenic content of drinking water in villages in northern India. A concept of arsenicosis. J Assoc Physicians India 24: 599-604.

4. Garai R, Chakraborty AK, Dey SB, Saha KC (1984) Chronic arsenic poisoning from tube-well water. J Indian Med Assoc 82: 34-35.

5. Dhar RKr, Biswas BKr, Samanta G, Mandal BKr, Chakraborti D, et al. (1997) Groundwater arsenic calamity in Bangladesh. Current Science 73: 48.

6. Shrestha RR, Shrestha MP, Upadhyay NP, Pradhan R, Khadka R, et al. (2003) Groundwater arsenic contamination, its health impact and mitigation program in Nepal. J Environ Sci Health A Tox Hazard Subst Environ Eng 38: 185-200.

7. Chakraborti D, Mukherjee SC, Pati S, Sengupta MK, Rahman MM, et al. (2003) Arsenic groundwater contamination in Middle Ganga Plain, Bihar, India: a future danger? Environ Health Perspect 111: 1194-1201.

8. Chakraborti D, Rahman MM, Paul K, Chowdhury UK, Sengupta MK, et al. 
Citation: Chaurasia N, Mishra A, Pandey SK (2012) Finger Print of Arsenic Contaminated Water in India-A Review. J Forensic Res 3:172. doi:10.4172/2157-7145.1000172

Page 4 of 4

(2002) Arsenic calamity in the Indian subcontinent What lessons have been learned? Talanta 58: 3-22.

9. Bhattacharjee S, Chakravarty S, Maity S, Dureja V, Gupta KK (2005) Metal contents in the groundwater of Sahebgunj district, Jharkhand, India, with special reference to arsenic. Chemosphere 58: 1203-1217.

10. Chakraborti D, Sengupta MK, Rahman MM, Ahamed S, Chowdhury UK, et al. (2004) Groundwater arsenic contamination and its health effects in the GangaMeghna-Brahmaputra Plain. J Environ Monit 6: 74N-83N.

11. Fazal MA, Kawachi T, Ichion E (2001) Extent and severity of groundwater arsenic contamination in Bangladesh. Water International 26: 370-379.

12. Agency for Toxic Substances and Disease Registry (2007) Toxicological profile for arsenic. Draft for Public Comment. Atlanta GA [ATSDR].

13. Bhattacharya P,Chatterjee D, Jacks G (1997) Occurrence of arseniccontaminated groundwater in alluvial aquifers from delta plains, Eastern India: Option for safe drinking water supply. International Journal of Water Resources Development 13: 79-92.

14. Nickson RT, McArthura JM, Ravenscroft P, Burgessa WG, Ahmed KM (2000) Mechanism of arsenic release to groundwater, Bangladesh and West Bengal. Appl Geochem 15: 403-413.

15. McArthura JM, Hudson-Edwardsc KA, Mishrab R, Purohitb R, Ravenscroftd $P$, et al. (2004) Natural organic matter in sedimentary basins and its relation to arsenic in anoxic groundwater: the example of West Bengal and its worldwide implications. Appl Geochem 19: 1255-1293.

16. Acharyya SK, Shah BA (1997) Risk of arsenic contamination in groundwater affecting the Ganga Alluvial Plain, India. Environ Health Perspect 112: A-19-A20.
17. Kunar S (2009) Arsenic in ground water in india: An overview. BHU-JAL journal 24:1-9.

18. Kinniburgh DG, Smedley PL (2001) arsenic contamination of groundwater in Bangladesh. British Geological Survey (WC/00/19).

19. SOES, Ground water Arsenic Contamination in U.P, Jharkhand, North Eastern States.

20. Report of the Central Team on Arsenic mitigation in rural drinking water sources in Ballia district, Uttar Pradesh State 14-17 September 2011, Ministry of Drinking Water and Sanitation Government of India New Delhi.

21. Harvey CF, Ashfaque KN, Yu W, Badruzzaman ABM, Ali MA, et al. (2006) Groundwater dynamics and arsenic contamination in Bangladesh. Chem Geology 228: 112-136.

22. Guha Mazumder DN (2008) Chronic arsenic toxicity \& human health. Indian Med Res 128: 436-447.

23. Datta DV, Kaul MK (1976b) Arsenic content of tubewell water in villages in northern India. A concept of arsenicosis. J Assoc Phys India 24: 599-604.

24. Groundwater arsenic contamination and arsenocosis patients in Uttar Pradesh (UP), India: report. Kolkata: School of Environmental Studies, Jadavpur University, 2005a: 1-21.

25. Report: Groundwater arsenic contamination and people suffering from arsenocosis from Jharkhand state in Middle Ganga Plain, India, January 2004 Kolkata: School of Environmental studies, Jadavpur University, 2005b:1-16.

26. Pandey PK, Khare RN, Sharma R, Sar SK, Pandey M, et al. (1999) Arsenicosis and deteriorating groundwater quality: unfolding crisis in central-east Indian region. Curr Sci 77: 686-693. 